\title{
Systems developed for application as self-cleaning surfaces and/or antimicrobial properties: a short review on materials and production methods
}

\author{
(Sistemas desenvolvidos para aplicação como superfícies \\ autolimpantes e/ou propriedades antimicrobianas: uma breve \\ revisão sobre materiais e métodos de produção)
}

\author{
M. P. Madeira', A. O. Lobo ${ }^{1}$, B. C. Viana ${ }^{1}$, E. C. Silva-Filho ${ }^{1}$, J. A. Osajima ${ }^{{ }^{*}}$ \\ ${ }^{1}$ Universidade Federal do Piaui, Interdisciplinary Laboratory for Advanced Materials, 64049-550, Teresina, PI, Brazil
}

\begin{abstract}
Herein we present a short review of different materials and techniques that have been used for the production of surfaces with selfcleaning and/or antimicrobial properties. From this, it was verified that titanium dioxide was the most frequently used compound to obtain surfaces with these properties; however, other materials such as silica, zinc and silver have also been used for this purpose. The spin-coating and dip-coating techniques were the most used techniques, and the bacteria Staphylococcus aureus and Escherichia coli were the most used in the antimicrobial assays. The analyzed studies showed that it is possible to obtain surfaces with both selfcleaning and/or antimicrobial properties, as well as with photocatalytic activity. Regarding possible applications, it is possible to highlight the interest in the production of glass and medical devices with self-cleaning and/or antimicrobial action.
\end{abstract}

Keywords: self-cleaning, antimicrobial, materials, techniques, photocatalytic.

Resumo

Esta minirrevisão apresenta materiais e técnicas que têm sido utilizados para a produção de superfícies autolimpantes elou antimicrobianas. A partir dos trabalhos analisados constatou-se grande utilização do dióxido de titânio para se obter superfícies com essas propriedades, porém materiais como sílica, zinco e prata também têm sido utilizados com esse propósito. As técnicas spincoating e dip-coating foram as mais utilizadas e as bact érias Staphylococcus aureus e Escherichia coli foram as mais empregadas nos ensaios antimicrobianos. Os trabalhos analisados mostram que é possivel se obter superficies com propriedade autolimpante el ou antimicrobiana, além de atividade fotocatalítica. Com relação a possíveis aplicações, pode-se destacar o interesse na produção de vidros e dispositivos médicos apresentando autolimpeza elou ação antimicrobiana.

Palavras-chave: autolimpante, antimicrobiano, materiais, técnicas, fotocatalítico.

\section{INTRODUCTION}

Many research efforts have been carried out to identify materials that can confer self-cleaning properties on glass $[1,2]$, plastic [3, 4], metal [5-7], textile [8,9] and ceramic tile $[10,11]$ surfaces. Midtdal and Jelle [12], for example, reported a study on self-cleaning glasses, now available on the market, and methods for measuring the self-cleaning property of such surfaces. The coating obtained from these materials can be hydrophilic, having either a strong affinity for water, or can be hydrophobic to repel water [13]. The water contact angle is a parameter used to evaluate whether a surface has hydrophilic or hydrophobic character. This angle is formed by a drop of the liquid at the point of intersection between the solid-liquid-vapor phases and lies between the plane tangent to the surface of the liquid and the plane

*josyosajima@ufpi.edu.br

(D) https://orcid.org/0000-0001-7089-3244 tangent to the surface of the solid [14]. Fig. 1 represents a drop on a solid, where $\theta$ stands for the contact angle and $\gamma_{\mathrm{lv}}, \gamma_{\mathrm{sv}}$ and $\gamma_{\mathrm{sl}}$ are the interfacial tensions between the liquidvapor, solid-vapor and solid-liquid phases, respectively. The pioneering correlation of the variables (Fig. 1) is calculated by Young's equation (Eq. A), which represents the vector sum of forces (interfacial tensions) at the three-phase intersection point when a drop of a liquid rests on a solid surface. Young's equation assumes an ideal solid surface, which is rigid and chemically homogeneous. The methods developed for the measurement of contact angles are: video camera on a goniometer, drop dimensions, sliding drop on an inclined plate, captive bubble and static Wilhelmy plate [14]. When the contact angle is less than $90^{\circ}$, the surface is hydrophilic, and if it is greater than $90^{\circ}$, the surface is hydrophobic. Moreover, when the contact angle is $0^{\circ}$, the surface is considered superhydrophilic, and if the angle is equal to or greater than $150^{\circ}$, the surface is superhydrophobic [13]. Fig. 2 illustrates the wettability from the interaction of 
the drop with superhydrophobic, hydrophobic, hydrophilic and superhydrophilic surfaces.

$$
\gamma_{\mathrm{SV}}=\gamma_{\mathrm{sl}}+\gamma_{\mathrm{lv}} \cos \theta
$$

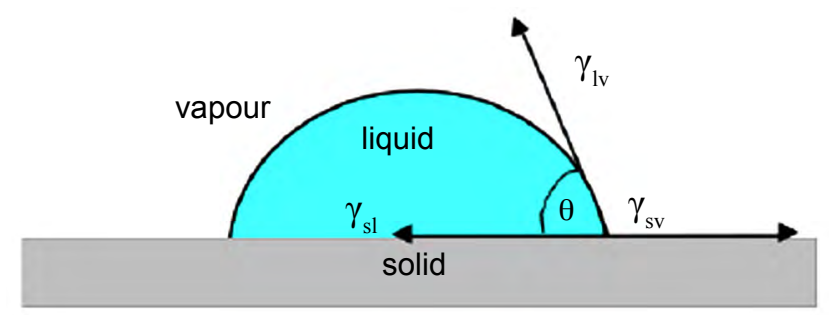

Figure 1: Schematic of a liquid drop on a solid surface showing the contact angle $\theta$ and interfacial tensions between liquid-vapor $\left(\gamma_{\mathrm{lv}}\right)$, solid-vapor $\left(\gamma_{\mathrm{sv}}\right)$ and solid-liquid $\left(\gamma_{\mathrm{sl}}\right)$.

[Figura 1: Esquema de uma gota líquida sobre uma superficie sólida mostrando o ângulo de contato $\theta$ e tensões interfaciais entre líquido-vapor $\left(\gamma_{l v}\right)$, sólido-vapor $\left(\gamma_{s v}\right)$ e sólido-líquido $\left.\left(\gamma_{s}\right) \cdot\right]$
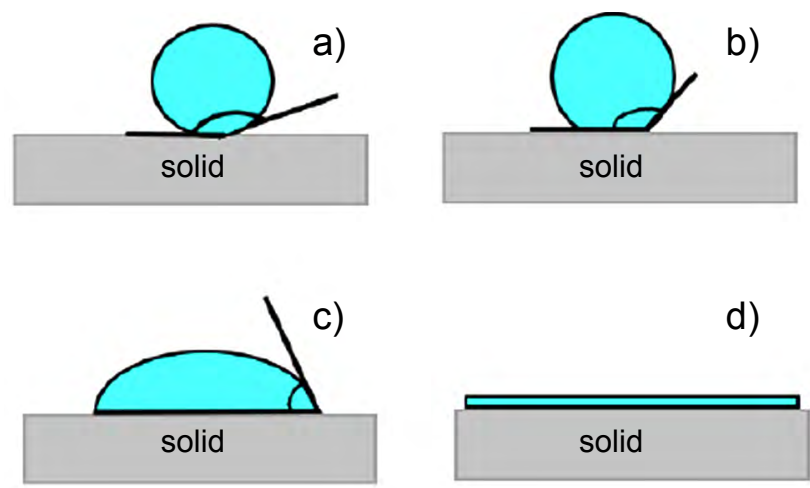

d)

Figure 2: Degree of wettability of surfaces: a) superhydrophobic; b) hydrophobic; c) hydrophilic; and d) superhydrophilic.

[Figura 2: Grau de molhabilidade de superficies: a) superhidrofóbica; b) hidrofóbica; c) hidrofilica; e d) super-hidrofilica.]

In the self-cleaning process of a hydrophilic surface, the water droplets form a thin layer on the surface and this uniform spreading allows faster drying and greater transparency of the surface. In other words, it prevents fogging of the surfaces. Conversely, on hydrophobic surfaces, the droplets roll on the surface and transport the dirt [15, 16]. One of the most used materials in self-cleaning surfaces with photocatalytic activity is titanium dioxide $\left(\mathrm{TiO}_{2}\right)$. Due to its antimicrobial activity, this material is also applied in studies of antimicrobial surfaces. This oxide is a non-toxic semiconductor, chemically inert in the absence of light, with long durability, chemical stability, availability and relatively low cost [16-18]. $\mathrm{TiO}_{2}$ decomposes organic contaminants through a photocatalytic effect and promotes the dispersion of water on the surface in order to complete the self-cleaning process [17]. Briefly, the photocatalytic properties of $\mathrm{TiO}_{2}$ are derived from the formation of electron and hole which occurs under the absorption of the light. The electrons in the conduction band participate in reduction processes using molecular oxygen to produce superoxide radical anion $\left(\cdot \mathrm{O}_{2}^{-}\right)$. The holes in the valence band react with adsorbed water molecules leading to produce hydroxyl radicals $(\cdot \mathrm{OH})$. Both radicals (hydroxyl and superoxide anion) are responsible for self-cleaning property. The property of photoinduced hydrophilicity/superhydrophilicity is promoted when a small proportion of the hole is trapped at lattice oxygen sites and may react with $\mathrm{TiO}_{2}$ itself that favors the formation of hydroxyl groups less thermodynamically stable and a high energy surface [18]. Fig. 3 illustrates the steps of the selfcleaning of a $\mathrm{TiO}_{2}$ coated surface from its photocatalytic activity and photoinduced hydrophilicity.

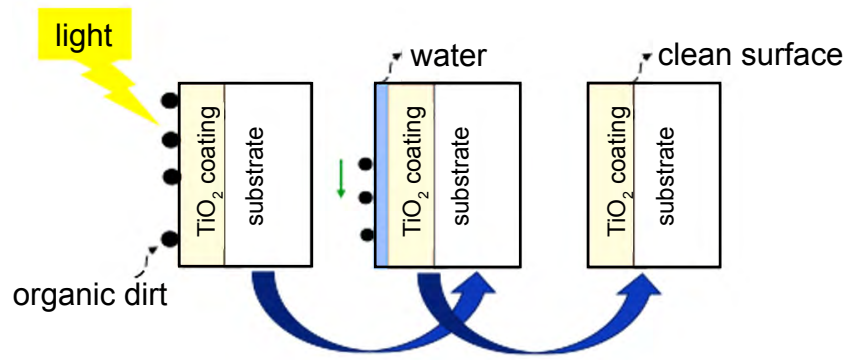

Figure 3: Self-cleaning process with photocatalytic degradation of organic contaminant on a surface coated with $\mathrm{TiO}_{2}$ and removal of the contaminant by water.

[Figura 3: Processo autolimpante com degradação fotocatalítica de contaminante orgânico em uma superficie revestida com $\mathrm{TiO}_{2}$ e remoção do contaminante pela água.]

Surfaces with antimicrobial activity are important since they can be used in hospital environments or in areas at risk of contamination by microbial agents. The ISO 20743 defines antibacterial activity as "activity of an antibacterial finish used to prevent or mitigate the growth of bacteria, to reduce the number of bacteria or to kill bacteria" [19]. Studies either on antimicrobial coatings or the incorporation of metals into the glass to confer antimicrobial properties have been important strategies to obtain new materials that can be used to reduce infections or diseases. For example, metals such as silver, copper and zinc have been used for this purpose [20, 21]. In addition, these coatings can be incorporated with antibiotics, quaternary ammonium compounds and light-activated molecules, such as $\mathrm{TiO}_{2}$ [22]. Surfaces capable of photocatalytic oxidation are an alternative for antimicrobial surfaces in the hospital environment due to their self-regenerating biocidal effect that makes such surfaces active for long periods of time. The electron $\left(\mathrm{e}^{\mathrm{e}}\right) / \mathrm{hole}\left(\mathrm{h}^{+}\right)$pair in the presence of water and oxygen generates superoxide radical anion $\left(\cdot{ }^{-}{ }^{-}\right)$, hydroxyl radical $(\cdot \mathrm{OH})$ and hydrogen peroxide $\left(\mathrm{H}_{2} \mathrm{O}_{2}\right)$, which are responsible for the photocatalytic biocidal activity of $\mathrm{TiO}_{2}[22,23]$. The $\cdot \mathrm{OH}$ radicals are believed to be the main species in photocatalytic biocidal activity, which are capable of destroying bacteria once they attack the cell wall leading to its punctures, breaking DNA strands and leading to the degradation of cytoplasmic membrane [23-27]. Fig. 4 illustrates the photocatalytic and self-cleaning disinfection of $\mathrm{TiO}_{2}$.

In a recent publication, Henriques et al. [28] presented methods of manufacturing and the antimicrobial performance of surfaces containing graphene-based materials. These surfaces can be obtained by freestanding 


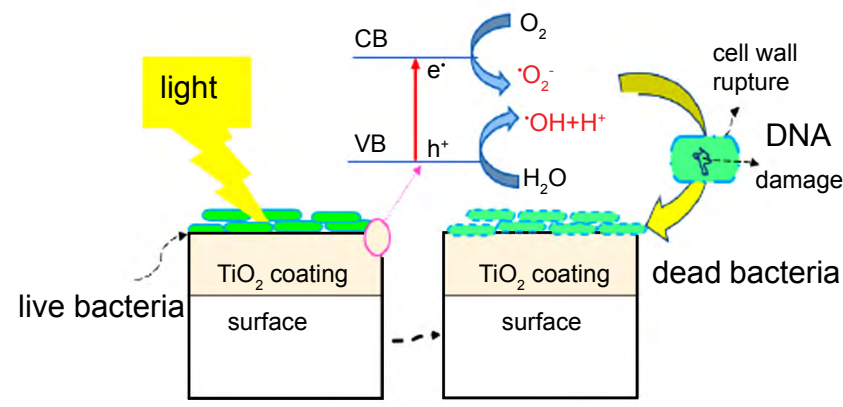

Figure 4: Antimicrobial process of a surface coated with $\mathrm{TiO}_{2}$. [Figura 4: Processo antimicrobiano de uma superficie revestida com $\mathrm{TiO}_{2}$.]

films, coatings, or bulk composites. Coating techniques such as the Langmuir-Blodgett, spray-coating, drop-casting, electrophoretic deposition, chemical vapor deposition, spincoating and dip-coating on various substrates (glass, metal, PET, cotton) were cited in the study [28]. Fig. 5 illustrates the spin-coating and dip-coating techniques. In the spincoating technique (Fig. 5a), an amount of solution of interest is deposited on a rotating substrate and after the evaporation of the solvent, the film is formed. In dip-coating technique (Fig. 5b), a film is formed on a substrate that is vertically submerged into the solution of interest, withdrawn and dried by the evaporation of solvent $[29,30]$. Sjollema et al. [31] reported in vitro evaluation methods of antimicrobial surface designs, including industry standards, according to the effectiveness of their antimicrobial mechanisms. The methods reported included the agar zone of inhibition, suspension, those comprising a high area-to-volume ratio, biofilm- and adhesion-based methods, antimicrobialrelease, contact-killing, and non-adhesivity mechanisms. The objective herein is to present a review regarding published articles on the materials and techniques used to obtain surfaces with self-cleaning and/or antimicrobial properties.

a)

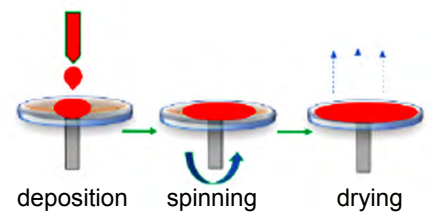

Figure 5: Techniques for the deposition of thin films: a) spincoating; and b) dip-coating.

[Figura 5: Técnicas de deposição de filmes finos: a) spin-coating; e b) dip-coating.]

\section{METHODOLOGY}

The search for papers was carried out from March to June 2018. The articles published from 2010 to 2018 were selected from the Web of Science database, regarding self-cleaning and/or antimicrobial surfaces, and different materials and methods. In addition, the papers were analyzed in order to identify the characterizations such as photocatalytic studies and analysis of the wettability of the surfaces with/without light irradiation. In most of the selected papers, the substrate used was glass, which was the focus of this short review. In addition, the selected papers were those in which the selfcleaning and/or antimicrobial surface was obtained from its coating with certain materials.

\section{RESULTS AND DISCUSSION}

Materials and techniques for the production of selfcleaning surfaces

Different materials, such as oxide nanoparticles and/ or polymers, and various techniques, such as spin-coating, dip-coating, doctor blading, layer-by-layer, magnetron sputtering and aerosol assisted chemical vapor deposition, have been used to produce surfaces with self-cleaning properties. Studies on the production of self-cleaning surfaces are described in detail below.

Spin-coating technique: Anandan et al. [32] developed thin films of $\mathrm{TiO}_{2}$ loaded on graphene sheets on a glass substrate by spin-coating. The films presented properties such as optical transparency, electroconductivity, and photocatalytic activity, under UV irradiation, and was two times faster to degrade the methylene blue dye than pure $\mathrm{TiO}_{2}$ films. In addition, the film showed superhydrophilic properties. According to the authors [32], these films can be used in several indoor applications. Adak et al. [33] developed transparent films of $\mathrm{TiO}_{2}$ doped with vanadium and silicon dioxide $\left(\mathrm{V}-\mathrm{TiO}_{2} / \mathrm{SiO}_{2}\right)$ on glass by spin-coating. The films exhibited antireflection property, superhydrophilicity, and photocatalytic activity in the degradation of methylene blue under visible light. The effect of plasma treatment on the wettability of films was also investigated. After treatment with $\mathrm{O}_{2}$ plasma, for all $\mathrm{V}-\mathrm{TiO}_{2} / \mathrm{SiO}_{2}$ compositions analyzed, the contact angles of water were approximately $0^{\circ}$. According to the authors [33], the properties of the coating obtained are suitable for architectural glass and photovoltaic (PV) module with high solar energy conversion efficiency. Katsumata et al. [34] used niobia nanosheets $\left(\left[\mathrm{Nb}_{3} \mathrm{O}_{8}\right]^{-}\right)$ and sodium ions to obtain sodium niobate $\left(\mathrm{NaNbO}_{3}\right)$ and, from this material, prepared $\mathrm{NaNbO}_{3}$ films as self-cleaning glass for vehicles. The films were obtained by spin-coating using glass as a substrate. When heated to a temperature equal or greater than $450{ }^{\circ} \mathrm{C}$, the films exhibited good optical transparency, high hardness, adhesion, and photoinduced hydrophilicity under UV radiation, though there was low photocatalytic oxidation activity of methylene blue. Liang et al. [35] produced thin films of vanadium dioxide doped with tungsten for application in smart windows with self-cleaning and energy-saving properties. The films were obtained by spin-coating on fused quartz and presented excellent hydrophilicity and thermochromism. Liao et al. [36] reported a significant improvement in the photocatalytic activity of $\mathrm{TiO}_{2}-\mathrm{P} 25$ films modified with gold nanoparticles aiming at the manufacture of plasmonic photocatalysts. They used silicon wafers as substrates for the films and the technique of spin-coating for the deposition of $\mathrm{TiO}_{2}$. The gold 
nanoparticles were synthesized by cluster beam deposition. In the photocatalytic test, stearic acid was deposited on the films by spin-coating, and then the films were exposed to UV light $(365 \mathrm{~nm})$ and green light $(515 \mathrm{~nm})$. The photocatalytic activity of the modified films with the gold nanoparticles was not influenced when using UV radiation; however, the activity was improved for films irradiated with a green light $(515 \mathrm{~nm})$.

Dip-coating technique: Jesus et al. [1] produced $\mathrm{TiO}_{2}$ and $\mathrm{TiO}_{2} / \mathrm{SiO}_{2}$ films for application in photovoltaic module glass to promote self-cleaning superhydrophilicity. Both films were deposited on glass by dip-coating and showed high transmittance, superhydrophilicity after irradiation with UV light, adhesion and resistance to abrasion. In addition, $\mathrm{TiO}_{2} / \mathrm{SiO}_{2}$ films presented low contact angles before and after irradiation, and maintained their superhydrophilicity in the dark, as opposed to pure $\mathrm{TiO}_{2}$ films. Vodisek et al. [37] synthesized transparent thin films of titanium dioxide, zirconia and silicon dioxide $\left(\mathrm{TiO}_{2}-\mathrm{ZrO}_{2}-\mathrm{SiO}_{2}\right)$ with different amounts of zirconia. In order to obtain better adhesion of the films on the glass, the authors used a silica paste. The films were obtained by dip-coating. The UV-vis spectra of the films indicated high transmittance in the visible region. In addition, the photocatalytic activity of $\mathrm{TiO}_{2}$ did not improve with the addition of zirconia, but decreased with increasing zirconia content. The catalyst surface with methyl stearate (model organic pollutant) deposited was irradiated with UVA light and the water contact angle on the surface was measured as a function of different irradiation times. The results showed a fast reduction of the contact angle in the sample without zirconia and the rate reduction slowed in the sample with higher zirconia content. However, the sample with higher zirconia content had better mechanical stability (scratch resistance). According to the authors [37], a zirconia content of around $10 \mathrm{~mol} \%$ was the most adequate to combine the photocatalytic activity and mechanical robustness of the films. In a recent study, Liang et al. [38] produced $\mathrm{TiO}_{2}$ films obtained by the sol-gel method. The sol was formed from the hydrolysis of tetrabutyl titanate using different hydrolysis control agents. The study aimed to evaluate both the effects of the hydrolysis control agent on the structure of the particles after calcination of $\mathrm{TiO}_{2}$ and the self-cleaning property of $\mathrm{TiO}_{2}$ films. Among the hydrolysis control agents, acetylacetone provided the most stable $\mathrm{TiO}_{2}$. The films were obtained by dip-coating into the $\mathrm{TiO}_{2}$ sol using glass as a substrate. The photocatalytic activity of the obtained $\mathrm{TiO}_{2}$ was very close to the activity of the $\mathrm{TiO}_{2}-\mathrm{P} 25$ and almost completely degraded a solution of methylene blue after 90 min of irradiation with UV light. The films calcined at $500{ }^{\circ} \mathrm{C}$ presented superhydrophilicity after $30 \mathrm{~min}$ of irradiation with UV light and effective antifogging ability.

Other techniques: Náfrádi et al. [2] obtained $\mathrm{TiO}_{2}$ nanowire films deposited on glass by doctor blading with excellent water scattering and photocatalytic activity. These films were used for self-cleaning glass applications. The photocatalytic test consisted of the degradation of methylene blue dye under UV radiation. In the glass covered with the film, the contact angle of the water was $12^{\circ}$, and outdoor tests showed that the samples have self-cleaning properties with significantly reduced $\mathrm{TiO}_{2}$ content compared to films fabricated with $\mathrm{TiO}_{2}$ nanoparticles. Patrocinio et al. [39] produced layer-by-layer films of nanoparticle $\mathrm{TiO}_{2}$ and tungsten trioxide $\left(\mathrm{WO}_{3}\right)$ on a fluorine-doped tin oxide substrate (FTO) and obtained films with hydrophilicity that increased after irradiation with UVA light. In the photocatalytic test, the films oxidized acetaldehyde gas when irradiated with UVA light and presented a photon efficiency higher than those observed for pure $\mathrm{TiO}_{2}$ films also obtained by layer-by-layer. According to the authors [2], the films were suitable for applications such as selfcleaning surfaces in windows and roofs. Purkayastha et al. [40] synthesized thin films of $\mathrm{SnO}_{2}$ and molybdenumdoped tin oxide $\left(\mathrm{Mo}-\mathrm{SnO}_{2}\right)$ on glass by thermal evaporation of $\mathrm{SnO}_{2}$ powder after its doping. The $\mathrm{Mo}-\mathrm{SnO}_{2}$ and $\mathrm{SnO}_{2}$ films presented water contact angles of $80.3^{\circ}$ and $79.8^{\circ}$, respectively. However, when irradiated with UV light, the contact angle values decreased to $11.4^{\circ}$ for $\mathrm{Mo}-\mathrm{SnO}_{2}$ and $15.5^{\circ}$ for $\mathrm{SnO}_{2}$, with a fast decrease for the $\mathrm{Mo}-\mathrm{SnO}_{2}$ films. For both films, after storage in the dark, there was an increase in the contact angle values. In addition, the films presented almost identical transmission spectra, indicating that it was possible to adjust the wettability of the films via the doping process without affecting their transparency; this demonstrates the feasibility of the films to be used for the creation of transparent, self-cleaning surfaces. Shaik et al. [41] synthesized nanostructured zinc films by thermal evaporation on glass, quartz, sapphire, lanthanum aluminate and yttria-stabilized zirconia. The films showed a nano-sheet morphology and were superhydrophobic. However, after heating at $500^{\circ} \mathrm{C}$, the partial oxidation of $\mathrm{Zn}$ to $\mathrm{ZnO}$ and a change in the morphology was observed, i.e. the films changed from $\mathrm{Zn}$ nano-sheets to $\mathrm{ZnO}$ nanowires. In addition, the $\mathrm{ZnO}$ films exhibited a transition from superhydrophobic to hydrophilic under irradiation with UV light. When stored in the dark, they regained their original hydrophobic state after $72 \mathrm{~h}$. According to the authors [41], nanostructured surfaces can be useful in selfcleaning, mechanical and oxidation resistance applications. Table I lists research efforts on materials and techniques for producing self-cleaning surfaces, describing the material application and their respective references.

It could be observed that nanoparticles of oxides with or without the use of combined polymers, and different techniques, have been used to produce self-cleaning surfaces for various applications. In some studies, the obtained surface showed photocatalytic activity and photoinduced hydrophilicity $[32,45]$. However, among the studies, the hydrophilicity of non-irradiated surfaces was also reported [33,35]. Antifogging capability is another important parameter in self-cleaning surfaces, as reported in $[38,42]$. It is also important to note that self-cleaning can be obtained on both hydrophobic and superhydrophobic surfaces $[41,43,44,48]$. 
Table I - Materials and techniques for producing self-cleaning surfaces.

[Tabela I - Materiais e técnicas para produzir superfícies autolimpantes.]

\begin{tabular}{|c|c|c|c|}
\hline Material & Technique/method & Application & Ref. \\
\hline $\mathrm{TiO}_{2}$ & e-beam evaporation & Self-cleaning superhydrophilic glass & {$[42]$} \\
\hline Nanostructured zinc oxide & $\begin{array}{l}\text { Ionic layer adsorption } \\
\text { and reaction; chemical } \\
\text { bath deposition }\end{array}$ & $\begin{array}{l}\text { Self-cleaning and gas sensing } \\
\text { applications }\end{array}$ & [43] \\
\hline $\begin{array}{l}\text { Silica nanoparticles, polyelectrolytes, } \\
\text { fluoroalkylsilane }\end{array}$ & Layer-by-layer & Self-cleaning photovoltaic cells & [44] \\
\hline $\begin{array}{c}\text { 2-chloro-3',4'-dihydroxyacetophenone } \\
\text { quaternized poly(ethylene glycol)-g- } \\
\text { [poly(dimethylamino methacrylate)], } \mathrm{TiO}_{2} \\
\text { nanoparticles }\end{array}$ & Catechol chemistry & $\begin{array}{c}\text { Photocatalytic and self-cleaning } \\
\text { applications }\end{array}$ & [45] \\
\hline Sodium titanate nanobelt, fluoroalkylsilane & $\begin{array}{l}\text { Electrophoretic } \\
\text { deposition }\end{array}$ & $\begin{array}{c}\text { Self-cleaning and antifogging } \\
\text { applications }\end{array}$ & [46] \\
\hline $\begin{array}{c}\mathrm{TiO}_{2} \text { nanoparticles, polyvinylpyrrolidone } \\
\text { (PVP), diethanolamine (DEA) }\end{array}$ & Electrospinning & $\begin{array}{l}\text { Application on windows, solar cells } \\
\text { and chemical sensors }\end{array}$ & [47] \\
\hline $\begin{array}{l}\mathrm{SiO}_{2}, 1 \mathrm{H}, 1 \mathrm{H}, 2 \mathrm{H}, 2 \mathrm{H}-\text { perfluorooctyl } \\
\text { trichlorosilane }\end{array}$ & $\begin{array}{l}\text { Non-lithographic, } \\
\text { anisotropic etching } \\
\text { technique }\end{array}$ & $\begin{array}{c}\text { Eyeglasses, solar cells and optical } \\
\text { instruments }\end{array}$ & [48] \\
\hline $\begin{array}{l}\text { Molybdenum-doped } \mathrm{TiO}_{2} \text { nanocomposite, } \\
\text { layered double hydroxide }\end{array}$ & Spray technique & $\begin{array}{l}\text { Photocatalytic self-cleaning of mineral } \\
\text { substrates }\end{array}$ & [49] \\
\hline $\mathrm{TiO}_{2}$, carbon nanotubes, polyethylenimine & Spin-coating & Self-cleaning glass & {$[50]$} \\
\hline $\begin{array}{l}\text { Zinc acetate, ethanolamine, } \mathrm{Ag} @ \mathrm{AgCl} \\
\text { particles }\end{array}$ & $\begin{array}{l}\text { Spin-coated; } \\
\text { impregnating } \\
\text { precipitation } \\
\text { photoreduction method }\end{array}$ & $\begin{array}{l}\text { Visible light photocatalysis, self- } \\
\text { cleaning }\end{array}$ & [51] \\
\hline $\begin{array}{l}\mathrm{TiO}_{2}, \text { silica nanostructures, } \\
\text { trimethylchlorosilane }\end{array}$ & Dip-coating & $\begin{array}{l}\text { Self-cleaning and photocatalytic } \\
\text { window glass }\end{array}$ & [52] \\
\hline $\mathrm{TiO}_{2}$ & $\begin{array}{l}\text { Direct current } \\
\text { magnetron sputtering }\end{array}$ & $\begin{array}{l}\text { Self-cleaning amorphous } \mathrm{TiO}_{2} \text { thin } \\
\text { films }\end{array}$ & [53] \\
\hline Polytetrafluoroethylene & $\begin{array}{l}\text { Aerosol-assisted } \\
\text { chemical vapor } \\
\text { deposition }\end{array}$ & $\begin{array}{l}\text { Transparent superhydrophobic } \\
\text { surfaces; self-cleaning and anti- } \\
\text { corrosion properties }\end{array}$ & [54] \\
\hline
\end{tabular}

\section{Self-cleaning combined with antimicrobial property}

Surfaces with antimicrobial properties are necessary for the reduction/killing of bacteria and the decrease of infections caused by these microorganisms. Some significant studies on this topic have been reported. For example, Jalvo et al. [55] synthesized self-cleaning antimicrobial surfaces by functionalizing porous glass microfiber filters and glass slides with $\mathrm{TiO}_{2}$ nanoparticles. The $\mathrm{TiO}_{2}$ suspension was spread on the glass slides by smearing and in the filters by impregnation. The functionalized filters showed methylene blue photodegradation that was 50 times faster than the glass slides functionalized under UVA $(365 \mathrm{~nm})$. The surfaces initially showed hydrophobicity, but acquired hydrophilicity after irradiation. Staphylococcus aureus (S. aureus) and Pseudomonas putida (P. putida) grew easily on $\mathrm{TiO}_{2}$-functionalized filters and slides, but after $2 \mathrm{~h}$ of irradiation (290-400 nm) virtually all cells became unviable due to membrane damage. Dunnill et al. [56] produced antimicrobial films containing silver nanoparticles on $\mathrm{TiO}_{2}$ films. $\mathrm{TiO}_{2}$ films deposited on glass by dip-coating were immersed in a solution of silver nitrate in methanol so that the silver nanoparticles were generated on the surface by UV-assisted reduction of the solution. The films presented antimicrobial activity for both Methicillin-resistant $S$. aureus (MRSA) and Escherichia coli (E. coli) bacteria under hospital illumination conditions. In addition, visible light irradiation induced both photocatalytic activity, with the photodegradation of stearic acid, and superhydrophilicity.

Hosseini-Zori [57] produced cobalt-doped $\mathrm{TiO}_{2}$ nanostructures using a reverse microemulsion method. The antimicrobial activity was confirmed by the inhibition of growth of the bacteria Pseudomonas aeruginosa ( $P$. aeruginosa), $S$. aureus and $E$. coli on glaze surface coated with Co-doped $\mathrm{TiO}_{2}$ nanostructures. The photocatalytic activity of the samples was investigated using Acid Red 1, Reactive Blue 21 and Acid Blue 74 dyes under UV 
Table II - Antimicrobial surfaces: materials, techniques, bacteria, and application.

[Tabela II - Superfícies antimicrobianas: materiais, técnicas, bactérias e aplicação.]

\begin{tabular}{|c|c|c|c|c|}
\hline Material & Technique/method & Bacterium & Application & Ref. \\
\hline $\begin{array}{l}\mathrm{TiO}_{2} \text {, silver nanoparticles, } \\
\text { single-wall carbon nanotubes }\end{array}$ & Dip-coating & Escherichia coli & $\begin{array}{l}\text { Self-cleaning, medical } \\
\text { devices or surfaces; } \\
\text { touchscreens }\end{array}$ & [59] \\
\hline $\begin{array}{c}\mathrm{TiO}_{2} \text { nanocrystalline, alanine, } \\
\text { silver nitrate }\end{array}$ & Dip-coating & $\begin{array}{c}\text { Escherichia coli, } \\
\text { Staphylococcus aureus }\end{array}$ & $\begin{array}{l}\text { Photocatalytic and } \\
\text { antimicrobial surface }\end{array}$ & [60] \\
\hline $\begin{array}{l}\text { Silver and zinc oxide } \\
\text { nanocomposite }\end{array}$ & Spin-coating & $\begin{array}{c}\text { Escherichia coli, } \\
\text { Staphylococcus aureus }\end{array}$ & Antimicrobial surface & [61] \\
\hline $\begin{array}{l}\text { Poly(N-vinylpyrrolidone-co- } \\
\text { maleic anhydride) (poly(NVP- } \\
\text { co-MA) }\end{array}$ & Grafting & $\begin{array}{c}\text { Escherichia coli, } \\
\text { Staphylococcus aureus }\end{array}$ & $\begin{array}{l}\text { Optical devices } \\
\text { (biomedical endoscopes, } \\
\text { ocean periscopes) }\end{array}$ & [62] \\
\hline $\begin{array}{l}\text { Poly(p-phenylene ethynylene), } \\
\text { poly(N-isopropylacrylamide), } \\
\text { polymerization initiators }\end{array}$ & Layer-by-layer & $\begin{array}{c}\text { Escherichia coli, } \\
\text { Staphylococcus aureus }\end{array}$ & Antimicrobial surfaces & [63] \\
\hline $\begin{array}{l}\text { Spermine, sodium } \\
\text { hexafluorostannate, epoxy } \\
\text { terminated silane }\end{array}$ & $\begin{array}{l}\text { Spermine-functionalized } \\
\text { surfaces }\end{array}$ & Escherichia coli & $\begin{array}{c}\text { Self-cleaning } \\
\text { antimicrobial surfaces }\end{array}$ & [64] \\
\hline $\begin{array}{l}\text { Titanium isopropoxide, } \\
\text { tetraethyl orthosilicate, } \\
\text { fluoroalkylsilane }\end{array}$ & Spin-coating & Escherichia coli & $\begin{array}{l}\text { Antimicrobial and easy } \\
\text { clean surface }\end{array}$ & [65] \\
\hline Zinc oxide, silver oxide & $\begin{array}{l}\text { Radio frequency } \\
\text { magnetron reactive } \\
\text { sputtering }\end{array}$ & $\begin{array}{l}\text { Staphylococcus aureus, } \\
\text { Escherichia coli }\end{array}$ & Bactericidal & [66] \\
\hline Diamond-like carbon, silver & Magnetron sputtering & Escherichia coli & Antibacterial & [67] \\
\hline $\begin{array}{l}\text { Titanium dioxide, iron, copper, } \\
\text { fluorine }\end{array}$ & $\begin{array}{l}\text { Radiofrequency plasma } \\
\text { enhanced chemical } \\
\text { vapor deposition }\end{array}$ & Escherichia coli & $\begin{array}{l}\text { Bactericidal and } \\
\text { photowetting effects }\end{array}$ & [68] \\
\hline
\end{tabular}

radiation. The results indicated a high percentage of dye degradation. The contact angle measurements were performed on both: a) glass coated with Co-doped $\mathrm{TiO}_{2}$ nanostructures by printing; and b) glaze coated with $\mathrm{Co}-$ doped $\mathrm{TiO}_{2}$ nanostructures by dip-coating and printing. Both films showed a decrease in the angle value and the surfaces were hydrophilic. Recently, Jalvo et al. [58] used an electrospray technique to create photocatalytic coatings of $\mathrm{TiO}_{2}$ on glass slides. By irradiating the surfaces with UV light, they became even more hydrophilic. In addition, the application of dark-light cycles with the use of solar simulated irradiation damaged the bacterial membrane of S. aureus and cell re-growth was not observed. According to the authors [58], the electrospray technique was efficient in creating self-cleaning surfaces with precisely dispersed photocatalytic particles that could prevent the accumulation of biofilms under stringent environmental conditions. Sasmal et al. [4] used copper nanoparticles to produce superhydrophobic surfaces on glass, silicon, cotton wool, textile and transparent sheets for applications such as self-cleaning, roll-off and oil/water separation. For this, the chemical reduction of copper acetate by hydrazine hydrate was performed. In addition, the nanoparticles deposited on glass presented antimicrobial activity against the bacteria Staphylococcus epidermidis (S. epidermidis), E. coli and Enterobacter cloacae (E. cloacae). Table II lists other studies on antimicrobial and self-cleaning surfaces, emphasizing the materials, techniques/methods of manufacture, the bacteria used in the antimicrobial evaluation, application, and reference.

It can be observed that different types of materials (metal nanoparticles, metal oxides, and polymers) and techniques/ methods have been employed to obtain surfaces with selfcleaning and antimicrobial properties. In the majority of analyzed papers either the antimicrobial activity occurs under light action or in the absence of surface irradiation $[60,62]$. The E. coli and $S$. aureus bacteria were the most used in those reported studies. It is also worth noting that the hydrophilic character was demonstrated by most of the obtained surfaces. However, Sasmal et al. [4] and Seo et al. [65] obtained antimicrobial activity on superhydrophobic and hydrophobic surfaces, respectively.

\section{FINAL REMARKS}

In this short review, research articles regarding 
the production of surfaces with self-cleaning and/or antimicrobial properties were presented and compared. We also emphasized some materials and techniques that have been used toward this aim. Because of the potential benefits of self-cleaning surfaces, more studies need to be conducted and the current techniques improved to make these materials more readily available and commercialized. A widely used material is $\mathrm{TiO}_{2}$; however, many others ( $\mathrm{Zn}, \mathrm{ZnO}, \mathrm{Ag}, \mathrm{SiO}_{2}, \mathrm{NaNbO}_{3}$ ) have been tested. Among the mentioned techniques, spin-coating and dip-coating were the most applied. Regarding the antimicrobial assays, the bacteria $S$. aureus and E. coli were the most used. Selfcleaning surfaces with different degrees of wettability were obtained in the research efforts. It was also worth noting that the photocatalytic property was important for the selfcleaning ability of several surfaces obtained.

\section{ACKNOWLEDGMENTS}

The authors would like to thank Ms. Jessica Fitzgerald, Communications Laboratory Fellow at Northeastern University, for providing English language corrections and suggestions.

\section{REFERENCES}

[1] M.A.M.L. Jesus, J.T.S. Neto, G. Timò, P.R.P. Paiva, M.S. Dantas, Appl. Adhes. Sci. 3, 5 (2015) 1.

[2] B. Náfrádi, G. Náfrádi, C.M. Hamka, L. Forró, E. Horváth, Langmuir 33 (2017) 9043.

[3] R. Fateh, A.A. Ismail, R. Dillert, D.W. Bahnemann, J. Phys. Chem. C 115 (2011) 10405.

[4] A.K. Sasmal, C. Mondal, A.K. Sinha, S.S. Gauri, J. Pal, T. Aditya, M. Ganguly, S. Dey, T. Pal, ACS Appl. Mater. Interfaces 6 (2014) 22034.

[5] J.C. Yu, W. Ho, J. Lin, H. Yip, P.K. Wong, Environ. Sci. Technol. 37 (2003) 2296.

[6] S. Ding, T. Xiang, C. Li, S. Zheng, J. Wang, M. Zhang, C. Dong, W. Chan, Mater. Des. 117 (2017) 280.

[7] Y. Cheng, S. Lu, W. Xu, K. Cao, J. Li, Yu Zheng, Surf. Coat. Technol. 333 (2018) 61.

[8] K. Qi, W.A. Daoud, J.H. Xin, C.L. Mak, W. Tanga, W.P. Cheunga, J. Mater. Chem. 16 (2006) 4567.

[9] C. Zhu, J. Shi, S. Xu, M. Ishimori, J. Sui, H. Morikawa, Cellulose 24 (2017) 2657.

[10] S. Niederhausern, M. Bondi, F. Bondioli, Int. J. Appl. Ceram. Technol. 10, 6 (2013) 949.

[11] A.L. Silva, M. Dondi, D. Hotza, Ceram. Int. 43 (2017) 11986.

[12] K. Midtdal, B.P. Jelle, Sol. Energy Mater. Sol. Cells 109 (2013) 126.

[13] J. Drelich, E. Chibowski, D.D. Meng, K. Terpilowskic, Soft Matter 7 (2011) 9804.

[14] H.Y. Erbil, in "Surface chemistry of solid and liquid interfaces", H.Y. Erbil (Ed.), Blackwell Publ., Turkey (2006) 1. [15] C. Euvananont, C. Junin, K. Inpor, P. Limthongkul, C. Thanachayanont, Ceram. Int. 34 (2008) 1067.
[16] I.P. Parkin, R.G. Palgrave, J. Mater. Chem. 15 (2005) 1689.

[17] P. Ragesh, V.A. Ganesh, S.V. Nair, A.S. Nair, J. Mater. Chem. A 2 (2014) 14773.

[18] K. Nakata, A. Fujishima, J. Photoch. Photobio. C Photochem. Rev. 13 (2012) 169.

[19] ISO 20743, "Textiles - determination of antibacterial activity of textile products", Int. Org. Stand. (2013).

[20] D. Guldiren, S. Aydin, Mater. Sci. Eng. C 78 (2017) 826.

[21] L. Drago, M. Toscano, M. Bottagisio, Materials 11, 326 (2018) 1.

[22] C. Adlhart, J. Verran, N.F. Azevedo, H. Olmez, M.M. Keinanen-Toivola, I. Gouveia, L.F. Melo, F. Crijns, J. Hosp. Infect. 99 (2018) 239.

[23] S. Banerjee, J. Gopal, P. Muraleedharan, A.K. Tyagi, B. Raj, Curr. Sci. 90 (2006) 1378.

[24] Y. Cai, M. Strømme, K. Welch, J. Biomater. Nanobiotechnol. 5 (2014) 200.

[25] U. Joost, K. Juganson, M. Visnapuu, M. Mortimer, A. Kahru, E. Nõmmiste, U. Joost, V. Kisand, A. Ivask, J. Photochem. Photobiol. B 142 (2015) 178.

[26] H.A. Foster, I.B. Ditta, S. Varghese, A. Steele, Appl. Microbiol. Biotechnol. 90 (2011) 1847.

[27] K.P. Kuhn, I.F. Chaberny, K. Massholder, M. Stickler, V.W. Benz, H.-G. Sonntag, L. Erdinger, Chemosphere 53 (2003) 71.

[28] P.C. Henriques, I. Borges, A.M. Pinto, F.D. Magalhães, Carbon 132 (2018) 709.

[29] J. Henry, K. Mohanraj, G. Sivakumar, S. Umamaheswari, Spectrochim. Acta A Mol. Biomol. Spectrosc. 143 (2015) 172.

[30] M.F.M. Yusoff, M.R.A. Kadir, N. Iqbal, M.A. Hassan, R. Hussain, Surf. Coat. Technol. 245 (2014) 102.

[31] J. Sjollema, S.A.J. Zaat, V. Fontaine, M. Ramstedt, R. Luginbuehl, K. Thevissen, J. Li, H.C. van der Mei, H.J. Busscher, Acta Biomater. 70 (2018) 12.

[32] S. Anandan, T.N. Rao, M. Sathish, D. Rangappa, I. Honma, M. Miyauchi, ACS Appl. Mater. Interfaces 5 (2013) 207.

[33] D. Adak, S. Ghosh, P. Chakrabarty, A. Mondal, H. Saha, R. Mukherjee, R. Bhattacharyya, Sol. Energy 155 (2017) 410. [34] K. Katsumata, S. Okazaki, C.E.J. Cordonier, T. Shichi, T. Sasaki, A. Fujishima, ACS Appl. Mater. Interfaces 2, 4 (2010) 1236.

[35] Z. Liang, L. Zhao, W. Meng, C. Zhong, S. Wei, B. Dong, Z. Xu, L. Wan, S. Wang, J. Alloys Compd. 694 (2017) 124.

[36] T.-W. Liao, S.W. Verbruggen, N. Claes, A. Yadav, D. Grandjean, S. Bals, P. Lievens, Nanomaterials 8, 30 (2018) 1.

[37] N. Vodisek, K. Ramanujachary, V. Brezová, U.L. Stangard, Catal. Today 287 (2017) 142.

[38] Y. Liang, S. Sun, T. Deng, H. Ding, W. Chen, Y. Chen, Materials 11, 450 (2018) 1.

[39] A.O.T. Patrocinio, L.F. Paula, R.M. Paniago, J. Freitag, D.W. Bahnemann, ACS Appl. Mater. Interfaces 6 (2014) 16859.

[40] D.D. Purkayastha, M.G. Krishna, V. Madhurima, Mater. Lett. 124 (2014) 21. 
[41] U.P. Shaik, D.D. Purkayastha, M.G. Krishna, V. Madhurima, Appl. Surf. Sci. 330 (2015) 292.

[42] C. Garlisi, G. Palmisano, Appl. Surf. Sci. 420 (2017) 83.

[43] M. Shaban, M. Zayed, H. Hamdy, RSC Adv. 7 (2017) 617.

[44] X. Li, J. He, W. Liu, Mater. Res. Bull. 48 (2013) 2522.

[45] S.M. Kim, I. In, S.Y. Park, Surf. Coat. Technol. 294 (2016) 75.

[46] Y. Lai, Y. Tang, J. Gong, D. Gong, L. Chi, C. Lin, Z. Chen, J. Mater. Chem. 22 (2012) 7420.

[47] F. Li, Q. Li, H. Kim, Appl. Surf. Sci. 276 (2013) 390.

[48] T. Son, E. Yang, E. Yu, K. Oh, M.-W. Moon, H.-Y. Kim, J. Mech. Sci. Technol. 31, 11 (2017) 5407.

[49] B. Miljević, J.M. van der Bergh, S. Vučetić, D. Lazar, J. Ranogajec, Ceram. Int. 43 (2017) 8214.

[50] Q. Yi, H. Wang, S. Cong, Y. Cao, Y. Wang, Y. Sun, Y. Lou, J. Zhao, Nanoscale Res. Lett. 11, 457 (2016) 1.

[51] J. Yu, D. Sun, T. Wang, F. Li, Chem. Eng. J. 334 (2018) 225.

[52] S. Park, J. Ceram. Process. Res. 16, 2 (2015) 227.

[53] H. Sabbah, J. Coat. Technol. Res. 14 (2017) 1423.

[54] A. Zhuang, R. Liao, S.C. Dixon, Y. Lu, S. Sathasivam, I.P. Parkin, C.J. Carmalt, RSC Adv. 7 (2017) 29275.

[55] B. Jalvo, M. Faraldos, A. Bahamonde, R. Rosal, J. Hazard. Mater. 340 (2017) 160.

[56] C.W. Dunnill, K. Page, Z.A. Aiken, S. Noimark, G. Hyett, A. Kafizas, J. Pratten, M. Wilson, I.P. Parkin, J. Photochem. Photobiol. A Chem. 220 (2011) 113.

[57] M. Hosseini-Zori, J. Photochem. Photobiol. B 178
(2018) 512.

[58] B. Jalvo, M. Faraldos, A. Bahamonde, R. Rosal, Chem. Eng. J. 334 (2018) 1108.

[59] Y. Won, K. Schwartzenberg, K.A. Gray, Chemosphere 208 (2018) 899.

[60] I.D. Vukoje, T.D. Tomaševic-Ilic, A.R. Zarubica, S. Dimitrijevic, M.D. Budimir, M.R. Vranješ, Z.V. Šaponjic, J.M. Nedeljkovic, Mater. Res. Bull. 60 (2014) 824.

[61] M. Visnapuu, M. Rosenberg, E. Truska, E. Nõmmiste, A. Sutka, A. Kahru, M. Rähn, H. Vija, K. Orupõld, V. Kisanda, A. Ivask, Colloids Surf. B Biointerfaces 169 (2018) 222.

[62] H. Guo, T. Xu, J. Zhang, W. Zhao, J. Zhang, C. Lin, L. Zhang, Chem. Eng. J. 351 (2018) 409.

[63] H.C. Pappas, S. Phan, S. Yoon, L.E. Edens, X. Meng, K.S. Schanze, D.G. Whitten, D.J. Keller, Appl. Mater. Interfaces 7 (2015) 27632.

[64] R. André, F. Natalio, M.N. Tahir, R. Berger, W. Tremel, Nanoscale 5 (2013) 3447.

[65] Y.S. Seo, Y.-H. Son, D.-J. Kim, W.-J. Cho, C.J. Raj, K.H. Yu, J. Nanosci. Nanotechnol. 14 (2014) 9510.

[66] K.-T. Chuang, H. Abdullah, S.-J. Leu, K.-B. Cheng, D.H. Kuo, H.-C. Chen, J.-H. Chien, W.-T. Hu, J. Photochem. Photobiol. A Chem. 337 (2017) 151.

[67] L.J. Wang, F. Zhang, A. Fong, K.M. Lai, P.W. Shum, Z.F. Zhou, Z.F. Gao, T. Fu, Thin Solid Films 650 (2018) 58.

[68] A. Sobczyk-Guzenda, W. Szymanski, A. Jedrzejczak, D. Batory, W. Jakubowski, S. Owczarek, Surf. Coat. Technol. 347 (2018) 66.

(Rec. 05/12/2018, Rev. 19/02/2019, Ac. 19/03/2019) 